\title{
Ochrobactrum ciceri sp. nov., isolated from nodules of Cicer arietinum
}

\author{
A. Imran, ${ }^{1}$ F. Y. Hafeez, ${ }^{1} \dagger$ A. Frühling, ${ }^{2}$ P. Schumann, ${ }^{2}$ K. A. Malik ${ }^{3}$ \\ and E. Stackebrandt ${ }^{2}$
}

\author{
Correspondence \\ A. Imran \\ asmaaslam2001@yahoo.com \\ F. Y. Hafeez \\ fauzia_y@yahoo.com
}

\author{
${ }^{1}$ National Institute for Biotechnology and Genetic Engineering (NIBGE), PO Box 577, Jhang Road, \\ Faisalabad, Pakistan \\ ${ }^{2} \mathrm{DSMZ}$ - German Collection of Microorganisms and Cell Cultures GmbH, Inhoffenstrasse 7B, \\ 38124 Braunschweig, Germany \\ ${ }^{3}$ Department of Biological Sciences, Forman Christian College University, Ferozepur Road, Lahore, \\ Pakistan
}

\begin{abstract}
A Gram-staining-negative, aerobic, rod-shaped, non-spore-forming bacterial strain, $\mathrm{Ca}-34^{\top}$, was isolated from nodules of chickpea (Cicer arietinum) in Pakistan and studied for its taxonomic affiliation. The almost full-length 16S rRNA gene sequence showed highest similarities to those of strains of the genus Ochrobactrum. Based on results of MALDI-TOF MS and 16S rRNA gene sequence similarity (98.6\%), strain $\mathrm{Ca}-34^{\top}$ and Ochrobactrum intermedium LMG $3301^{\top}$ are phylogenetic neighbours; the two strains shared DNA-DNA relatedness of $64 \%$. The fatty acid profile [predominantly $\mathrm{C}_{18: 1} \omega 7 c(67.7 \%)$ and $\mathrm{C}_{19: 0}$ cyclo $\omega 8 c(19.6 \%)$ ] also supported the genus affiliation. Metabolically, strain $\mathrm{Ca}-34^{\top}$ differed from other type strains of Ochrobactrum in many reactions and from all type strains in testing positive for gelatin hydrolysis and in testing negative for assimilation of alaninamide and L-threonine. Based on phenotypic and genotypic data, we conclude that strain $\mathrm{Ca}-34^{\top}$ represents a novel species, for which we propose the name Ochrobactrum ciceri sp. nov. (type strain Ca-34 ${ }^{\top}=\mathrm{DSM} 22292^{\top}=$ CCUG $57879^{\top}$ ).
\end{abstract}

The genus Ochrobactrum, class Alphaproteobacteria, was originally described by Holmes et al. (1988) and currently comprises 14 species isolated from different environments including soil and industrial environments (Lebuhn et al., 2000; Kämpfer et al., 2008; Huber et al., 2010), the rhizosphere and plants (Ngom et al., 2004; Trujillo et al., 2005; Tripathi et al., 2006; Zurdo-Piñeiro et al., 2007), animals (Kämpfer et al., 2003) and humans (Holmes et al., 1988; Velasco et al., 1998; Teyssier et al., 2005, 2007). Three nodulating species have been described that form nodules on Acacia (Ngom et al., 2004), Lupinus (Trujillo et al., 2005) and Cytisus (Zurdo-Piñeiro et al., 2007). Here, we report a novel strain, Ca-34 ${ }^{\mathrm{T}}$, that was isolated in 1996 from nodules of chickpea (Cicer arietinum) grown in Pakistan. Its taxonomic affiliation was assessed by a polyphasic approach and the data obtained show that this strain belongs to a novel species of Ochrobactrum.

tPresent address: Department of Biosciences, COMSATS Institute for Information Technology (CIIT), Chak Shazaad Campus, Park Road, Islamabad, Pakistan.

The GenBank/EMBL/DDBJ accession number for the 16S rRNA gene sequence of strain $\mathrm{Ca}-34^{\top}$ is DQ647056.

A dendrogram based on MALDI-TOF MS, ARDRA profiles and Biolog GN utilization data are available as complementary material with the online version of this paper.
Strain Ca- $34^{\mathrm{T}}$ was isolated from root nodules according to Vincent (1970) using yeast mannitol (YEM) agar (Bergersen, 1961). The culture used in further phenotypic and molecular studies was purified from a single colony after overnight incubation at $28 \pm 2{ }^{\circ} \mathrm{C}$ on nutrient agar (NA). Cells were Gram stained (Doetsch, 1981) and cell morphology was observed under a phase-contrast microscope at $\times 100$ magnification. Aminopeptidase and cytochrome oxidase activities (Bactident; Merck) were tested according to the manufacturer's recommendations. Catalase activity was tested by addition of $3 \% \mathrm{H}_{2} \mathrm{O}_{2}$ to bacterial smears on a glass slide. Susceptibility to various antibiotics was examined as described by Valverde et al. (2005) using antibioticsupplemented discs (Bioanalyse) on antibiotic sulfonamid sensitivity test agar (ASS agar; Merck). The analytical profile index was studied using QTS-24 (DESTO) and API 20NE (bioMerieux) according to the instructions of the manufacturers. Carbon source utilization was studied using the Biolog GN Microplate system and metabolic fingerprints were identified using the MicroLog database software. Indole acetic acid (IAA) production was quantified using HPLC as described by Tien et al. (1979) and the acetylene reduction assay was performed as described by Hafeez et al. (1995). Fatty acids were prepared, separated (Labrenz et al., 1998) and analysed on GC as described by Kämpfer \& Kroppenstedt (1996) using the Sherlock MIDI system 
(Sasser, 1990). Preparation of cell extracts and handling of samples for MALDI-TOF MS analyses were done as described by Cousin et al. (2008). The $16 \mathrm{~S}$ rRNA gene was amplified using universal primers P1 and P6 (Tan et al., 1997) and primers F4 and R2 (Romero et al., 1995; Velasco et al., 1998). recA amplification was performed using the primers and amplification conditions described by Scholz et al. (2006, 2008). Sequencing of the latter gene was undertaken by Seqlab (Göttingen, Germany).

Cells of strain Ca- $34^{\mathrm{T}}$ are Gram-negative (aminopeptidasepositive), aerobic (oxidase- and catalase-positive), motile, dumbbell-shaped short rods, commonly observed as single cells under the microscope. Growth occurs on YEM agar, LB agar and NA at $28-37{ }^{\circ} \mathrm{C}$. Colonies (2-3 mm diameter) are circular, off-white, mucoid and translucent with entire margins. Resistant to ampicillin $(10 \mu \mathrm{g})$, aztreonam $(30 \mu \mathrm{g})$, cefixime $(5 \mu \mathrm{g})$ and cephradine $(30 \mu \mathrm{g}) \quad(\beta$-lactams). Substrate assimilation (API 20NE; bioMérieux) read after $24 \mathrm{~h}$ incubation at $37^{\circ} \mathrm{C}$ showed positive reactions of strain $\mathrm{Ca}-34^{\mathrm{T}}$ for $o$-nitrophenyl $\beta$-galactopyranoside (ONPG), sodium malonate, urea hydrolysis, gelatin hydrolysis, tryptophan deaminase and nitrate reduction. Acid production was observed from glucose, maltose, mannose, arabinose, rhamnose, sorbitol, inositol and melibiose. Gelatin hydrolysis is a unique characteristic of strain Ca- $34^{\mathrm{T}}$, not reported for any of the described Ochrobactrum type strains. In the Biolog analysis (MicroPlate system), Ochrobactrum pseudogrignonense, which is phylogenetically distinct from strain Ca- $34^{\mathrm{T}}$, was not tested. Most strains were positive in $25-41$ reactions. Strain Ca- $34^{\mathrm{T}}$ and Ochrobactrum intermedium DSM $17986^{\mathrm{T}}$ shared 58 positive reactions and differed in 11 reactions, including utilization of certain lipids, sugars, acids and amino acids (see Supplementary Table S1, available in IJSEM Online), which is similar to the level of similarity between the phylogenetically closely related type strains of Ochrobactrum anthropi, O. lupini, O. cytisi and O. tritici. IAA was produced up to 6.5 p.p.m. Although nodule occupancy by strain Ca- $34^{\mathrm{T}}$ was confirmed using transmission electron microscopy and immunogold labelling (A. Imran and others, unpublished data), nitrogen fixation could not be confirmed in vitro. Moreover, primers reported to amplify nif and nod genes from other Ochrobactrum strains (Trujillo et al., 2005; Zurdo-Piñeiro et al., 2007) were negative for strain $\mathrm{Ca}-34^{\mathrm{T}}$.

The fatty acid pattern of strain Ca- $34^{\mathrm{T}}$ (Table 1) is similar to those of other Ochrobactrum type strains. Like these strains, strain Ca- $34^{\mathrm{T}}$ contains $\mathrm{C}_{18: 1} \omega 7 c(67.7 \%)$ and $\mathrm{C}_{19: 0}$ cyclo $\omega 8 c(19.6 \%)$ fatty acids, but the amounts detected were larger and smaller, respectively, than those reported for O. intermedium LMG $3301^{\mathrm{T}}$ and O. anthropi ATCC $49188^{\mathrm{T}}$. In addition, significant amounts of $\mathrm{C}_{18: 0}(4.4 \%)$, $\mathrm{C}_{16: 0}(2.6 \%)$ and $\mathrm{C}_{18: 1} 2-\mathrm{OH}(2.6 \%)$ were present.

As judged from the MALDI-TOF MS dendrogram, the spectra of some Ochrobactrum type strains differed significantly from each other (e.g. Ochrobactrum thiophenivorans DSM $7126^{\mathrm{T}}$ and Ochrobactrum rhizosphaerae DSM $19824^{\mathrm{T}}$ ), while others were highly similar (e.g. strain $\mathrm{Ca}-34^{\mathrm{T}}$ and O. intermedium DSM $17986^{\mathrm{T}}$ and O. anthropi

Table 1. Fatty acid methyl ester compositions of Ochrobactrum type strains

Strains: 1 , strain Ca- $34^{\mathrm{T}}$ (data from this study; values in parentheses show results for an independent replicate run); 2, O. intermedium DSM $17986^{\mathrm{T}}$ (data from this study, analysed after 48 h); 3, O. intermedium LMG $3301^{\mathrm{T}} ; 4$, O. anthropi ATCC $49188^{\mathrm{T}} ; 5$, O. grignonense DSM 13338 ${ }^{\mathrm{T}} ; 6$, O. tritici DSM $13340^{\mathrm{T}}$; 7, O. gallinifaecis DSM $15245^{\mathrm{T}}$ (data in columns 3-7 from Kämpfer et al., 2003); 8, O. lupini LMG 22726 ${ }^{\mathrm{T}}$ (Trujillo et al., 2005); 9, O. oryzae MTCC $4195^{\mathrm{T}}$ (Tripathi et al., 2006); 10, O. pseudintermedium ADV31 ${ }^{\mathrm{T}}$ (Teyssier et al., 2007); 11, O. thiophenivorans DSM $7216^{\mathrm{T}}$; 12 , O. rhizosphaerae $\mathrm{PR} 17^{\mathrm{T}}$ (data in columns 11 and 12 from Kämpfer et al., 2008); 13, O. pseudogrignonense CCUG 30717 ${ }^{\mathrm{T}}$; 14, O. haematophilum CCUG $38531^{\mathrm{T}}$ (data in columns 13 and 14 from Kämpfer et al., 2007). Values are percentages of total fatty acids. -, Not detected/not reported.

\begin{tabular}{|c|c|c|c|c|c|c|c|c|c|c|c|c|c|c|c|}
\hline \multirow[t]{2}{*}{ Fatty acid } & \multicolumn{2}{|r|}{1} & \multirow[t]{2}{*}{2} & \multirow[t]{2}{*}{3} & \multirow[t]{2}{*}{4} & \multirow[t]{2}{*}{5} & \multirow[t]{2}{*}{6} & \multirow[t]{2}{*}{7} & \multirow[t]{2}{*}{8} & \multirow[t]{2}{*}{9} & \multirow[t]{2}{*}{10} & \multirow[t]{2}{*}{11} & \multirow[t]{2}{*}{12} & \multirow[t]{2}{*}{13} & \multirow[t]{2}{*}{14} \\
\hline & $24 \mathrm{~h}$ & $48 \mathrm{~h}$ & & & & & & & & & & & & & \\
\hline $\mathrm{C}_{14: 0}$ & - & - & - & - & - & - & - & 0.7 & - & 0.1 & - & - & - & - & - \\
\hline$C_{16: 0}$ & 3.4 & $2.6(2.5)$ & 3.6 & 3.7 & 6.6 & 2.9 & 3.7 & 8.9 & 4.2 & 5.1 & 12.0 & 7.3 & 8.3 & 9.7 & 10.8 \\
\hline $\mathrm{C}_{17: 0}$ & - & $1.9(1.8)$ & 2.1 & 3.1 & 1.4 & 1.7 & 0.9 & - & 1.6 & 0.3 & 3.1 & 1.4 & 2.8 & 1.6 & 2.5 \\
\hline $\mathrm{C}_{18: 0}$ & 3.4 & $4.4(4.3)$ & 4.4 & 4.1 & 8.8 & 7.2 & 9.6 & 3.7 & 3.0 & 5.6 & 4.2 & 2.9 & 7.6 & 4.9 & 7.7 \\
\hline $\mathrm{C}_{18: 1} \omega 7 c$ & 67.6 & $67.7(67.3)$ & 72.6 & 25.8 & 45.6 & 31.6 & 77.9 & 28.8 & 70.8 & 65.2 & 29.3 & 40.9 & 61.5 & 19.2 & 32.7 \\
\hline $\begin{array}{l}\text { 11-Methyl } \\
\mathrm{C}_{18: 1} \omega 7 c\end{array}$ & 0.6 & - & - & - & - & 1.0 & - & - & - & - & - & 1.5 & - & 1.7 & - \\
\hline $\mathrm{C}_{19: 0}$ cyclo $\omega 8 \mathrm{c}$ & 15.6 & $19.6(19.4)$ & 10.4 & 57.4 & 32.7 & 50.2 & 5.9 & 47.2 & 4.3 & 16.5 & 39.8 & 34.9 & 11.2 & 57.0 & 43.2 \\
\hline
\end{tabular}




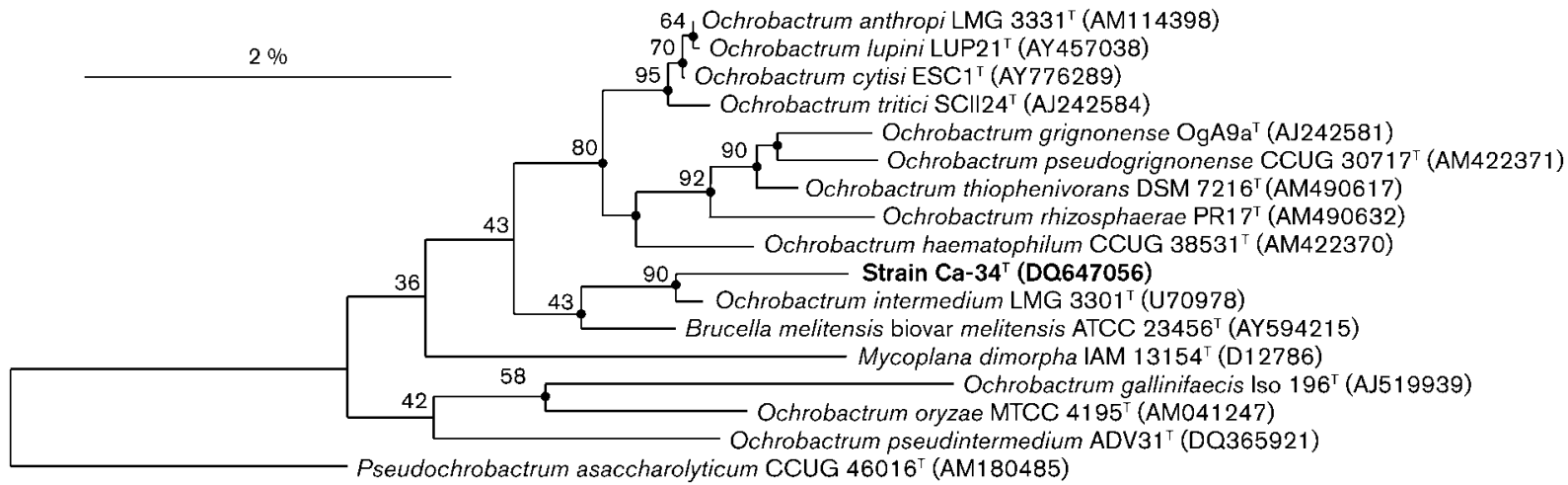

Fig. 1. Neighbour-joining phylogenetic tree based on $16 \mathrm{~S}$ rRNA gene sequences showing the relationship of strain Ca-34 ${ }^{\top}$, neighbouring Ochrobactrum type strains and Brucella melitensis biovar melitensis ATCC $23456^{\top}$. Branching points that are identical to those of the maximum-likelihood tree are indicated by filled circles. Numbers at branching points are bootstrap values $>35 \%$ (percentages of 1000 resamplings). Pseudochrobactrum asaccharolyticum CCUG $46016^{\top}$ served as an outgroup. Bar, $2 \%$ sequence divergence.

DSM 6882 ${ }^{\mathrm{T}}$, O. cytisi DSM $19778^{\mathrm{T}}$ and O. lupini DSM $16930^{\mathrm{T}}$ ) (Supplementary Fig. S1). The lack of congruence in dendrogram topology between 16S rRNA gene sequences and MALDI-TOF MS profiles has been noted previously in studies on members of Flavobacterium (Cousin et al., 2008; Ali et al. 2009).

Sequencing of the nearly complete $16 \mathrm{~S}$ rRNA gene of strain $\mathrm{Ca}-34^{\mathrm{T}}$ indicated the presence of a $46 \mathrm{nt}$ insertion at Escherichia coli $16 \mathrm{~S}$ rRNA position 187 that folds into a stem-loop structure when analysed through MFOLD (http:// www.mfold.burnet.edu.au/). This insertion has already been described in clinical isolates of $O$. anthropi including strain ADV1 (Teyssier et al., 2003) and O. intermedium isolates including strains CCUG 1838 and CCUG 44770 (Scholz et al., 2008) and has been reported to prolong helix H184 when placed on the Brucella suis 16S rRNA gene sequence secondary structure. Three $O$. anthropi isolates (GenBank accession numbers AM114410, AM11409 and AM490614), showing the highest 16S rRNA gene sequence similarity to strain Ca- $34^{\mathrm{T}}$, also possess this insertion. Most of the strains with this insertion are either clinical isolates or uncultured bacterial clones isolated from the environment. To our knowledge, this is the first report of this insertion in any plant-associated bacterium.

Teyssier et al. (2003) reported that the $46 \mathrm{bp}$ insertion showed no significant similarity with genome sequence data, but BLAST analysis of this $46 \mathrm{bp}$ sequence showed $100 \%$ similarity to the $16 \mathrm{~S}$ rRNA gene sequences of some uncultured bacterial clones (GenBank accession numbers EU769179, EU149209 and DQ917822), a few isolates of $O$. anthropi and $O$. intermedium and some partially characterized $O$. tritici isolates.

Omitting the insert, BLASTN analysis (Altschul et al., 1997) was followed by a thorough phylogenetic analysis by aligning the sequence of strain $\mathrm{Ca}-34^{\mathrm{T}}$ to the database of the 'All-species living tree' (http://arb-silva.de/projects/ living-tree/). Binary comparisons showed $99 \%$ similarity to a cloned sequence of a phenol-degrading uncultured Ochrobactrum sp. P3 and to two reclassified O. intermedium strains, CCUG 44770 (GenBank accession no. AM114410) and CCUG 1838 (AM114409, AM490614) (Scholz et al., 2008), which are not closely related to the type strain of this species (not shown).

Strain Ca- $34^{\mathrm{T}}$ showed the highest $16 \mathrm{~S}$ rRNA gene sequence similarity to the type strain of O. intermedium (98.6\%), while similarity to other type strains of the genus was lower (e.g. O. tritici SCII $24^{\mathrm{T}}, 97.0 \%$; O. anthropi LMG $3331^{\mathrm{T}}$, $96.8 \%$ ), ranging between 94.6 and $97 \%$. Distances were

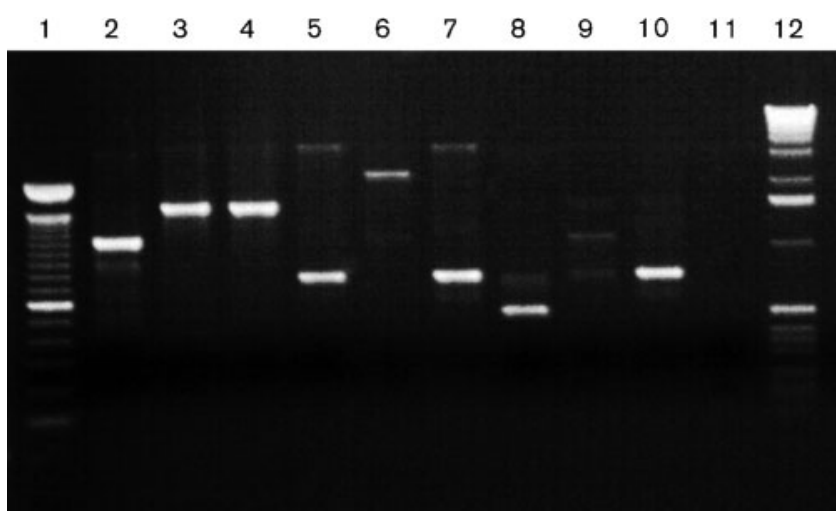

Fig. 2. Representative RAPD profiles of strain $\mathrm{Ca}-34^{\top}$ and some strains of Ochrobactrum generated with primer OPC-13. Lanes: 1, DNA marker (100 bp); 2, strain Ca-34 ${ }^{\top} ; 3$, O. tritici DSM 13341; 4, O. tritici DSM $13340^{\top} ; 5$ and 7, O. Iupini LMG $22726^{\top} ; 6,0$. oryzae DSM $17471^{\mathrm{T}}$; 8, O. gallinifaecis DSM $15295^{\mathrm{T}} ; 9$, O. intermedium DSM $17986^{\mathrm{T}}$; 10, O. anthropi DSM $6882^{\mathrm{T}} ; 11$, negative control; 12, DNA marker (1 kb). 
calculated according to Kimura's two-parameter model (Kimura, 1980). A phylogenetic tree (Fig. 1) was inferred using the neighbour-joining method (Saitou \& Nei, 1987). Bootstrap analysis was based on 1000 resamplings. The topology of the phylogenetic tree, especially the relatedness of O. intermedium with Brucella species (represented by Brucella melitensis ATCC $23456^{\mathrm{T}}$ in Fig. 1) and the polyphyletic origin of several species assigned to the genus Ochrobactrum, is in accord with previously published studies on Ochrobactrum (Scholz et al., 2006, 2008).

Phylogenetic analysis (with and without the $46 \mathrm{bp}$ insertion; not shown) clearly showed that strain Ca- $34^{\mathrm{T}}$ and O. intermedium LMG $3301^{\mathrm{T}}$ form a separate group with some uncultured species and misclassified strains of O. anthropi, O. intermedium and Ochrobactrum sp. DASA 35030. As the binary $16 \mathrm{~S}$ rRNA gene sequence similarities were at the borderline at which DNA-DNA reassociation values are recommended (Stackebrandt \& Ebers, 2006), hybridization analysis was performed between strain Ca- $34^{\mathrm{T}}$ and the type strains O. intermedium DSM $17986^{\mathrm{T}}$ and $O$. anthropi DSM $6882^{\mathrm{T}}$. DNA was isolated by chromatography on hydroxyapatite by the procedure of Cashion et al. (1977) which was carried out as described by De Ley et al. (1970) with the modifications described by Huß et al. (1983) using a model Cary 100 Bio UV/Vis spectrophotometer. DNA-DNA relatedness values were 64.0 and $52.1 \%$, respectively, with O. intermedium DSM $17986^{\mathrm{T}}$ and $O$. anthropi DSM $6882^{\mathrm{T}}$. For G $+\mathrm{C}$ content determination, DNA was analysed by HPLC (Shimadzu) according to Mesbah et al. (1989). The G+C content of strain $\mathrm{Ca}-34^{\mathrm{T}}$ was $58.8 \mathrm{~mol} \%$, which is within the range $54.5-59.0 \mathrm{~mol} \%$ reported for other Ochrobactrum type strains (Lebuhn et al., 2000; Teyssier et al., 2007).

To better resolve the phylogeny between strains highly related by $16 \mathrm{~S}$ rRNA gene sequence similarities, recA amplification and sequence analysis was attempted, follow-

Table 2. Differential biochemical properties of strain $\mathrm{Ca}-34^{\top}$ and reference Ochrobactrum type strains

Strains: 1 , strain Ca-34 ${ }^{\mathrm{T}} ; 2$, O. intermedium DSM $17986^{\mathrm{T}} ; 3$, O. anthropi DSM $6882^{\mathrm{T}} ; 4$, O. lupini DSM $16930^{\mathrm{T}} ; 5$, O. cytisi DSM $19778^{\mathrm{T}}$; 6, O. tritici DSM $13340^{\mathrm{T}} ; 7$, O. grignonense DSM $13338^{\mathrm{T}} ; 8$, O. rhizosphaerae DSM $19824^{\mathrm{T}}$; 9, O. thiophenivorans DSM $7216^{\mathrm{T}} ; 10$, O. gallinifaecis DSM $15295^{\mathrm{T}}$; 11 , O. pseudintermedium DSM $17490^{\mathrm{T}} ; 12$, O. oryzae DSM $17471^{\mathrm{T}}$. The table is arranged according to phylogenetic clustering. All data are from this study (for a detailed comparison, see Supplementary Table S1). +, Positive; -, negative; w, weakly positive.

\begin{tabular}{|c|c|c|c|c|c|c|c|c|c|c|c|c|}
\hline Assimilation of: & 1 & 2 & 3 & 4 & 5 & 6 & 7 & 8 & 9 & 10 & 11 & 12 \\
\hline Tween 80 & + & - & $\mathrm{w}$ & + & + & + & + & + & - & + & + & $t^{*}$ \\
\hline$N$-Acetyl-D-galactosamine & + & + & $+{ }^{a}{ }_{\dagger}$ & + & + & $+^{a}$ & $t^{a}$ & + & + & $-{ }^{a}$ & - & $t^{*}$ \\
\hline Adonitol & + & $+^{b}$ & + & + & + & $t^{*}$ & $-*$ & - & - & - & + & $t^{*}$ \\
\hline D-Arabitol & + & + & + & + & + & + & + & + & + & - & + & $t^{*}$ \\
\hline Cellobiose & + & $+^{a}$ & $+^{a}$ & $+\ddagger$ & + & $-{ }^{a}$ & $+\ddagger$ & - & + & $+\ddagger$ & + & - \\
\hline Gentiobiose & + & + & + & + & + & $--^{b}$ & $t^{*}$ & - & - & - & + & $-*$ \\
\hline L-Fucose & + & + & + & $+{ }^{b}$ & + & + & + & + & + & + & + & $+^{*}$ \\
\hline myo-Inositol & + & $t^{*}$ & + & $+\ddagger$ & + & + & + & - & + & - & + & $t^{*}$ \\
\hline D-Mannitol & + & $t^{*}$ & + & $+^{b}$ & + & + & + & + & + & - & - & $t^{*}$ \\
\hline L-Rhamnose & + & $-*$ & + & -ま & + & + & + & + & - & - & + & $t^{*}$ \\
\hline D-Sorbitol & + & + & + & + & + & + & $\mathrm{w}$ & + & - & - & + & $t^{*}$ \\
\hline Raffinose & - & + & - & - & - & - & - & - & - & - & - & - \\
\hline Sucrose & + & + & + & + & + & + & - & + & - & - & + & $t^{*}$ \\
\hline Trehalose & - & $+^{b}$ & $+{ }^{a}$ & + & + & $t^{*}$ & $-*$ & + & - & $-{ }^{a}$ & + & + \\
\hline Succinamic acid & - & + & - & $\mathrm{w}$ & + & - & - & - & $\mathrm{w}$ & $\mathrm{w}$ & - & + \\
\hline Citric acid & + & $t^{*}$ & + & $+^{b}$ & + & + & + & + & - & - & - & $-*$ \\
\hline D-Glucosaminic acid & + & $+^{b}$ & + & + & + & $+^{*}$ & $-*$ & - & - & - & + & + \\
\hline$\gamma$-Hydroxybutyric acid & + & $+^{b}$ & + & + & + & $-*$ & $t^{*}$ & + & - & - & + & + \\
\hline$p$-Hydroxyphenylacetic acid & - & - & - & - & - & - & - & - & + & - & - & + \\
\hline$\alpha$-Ketobutyric acid & - & + & - & + & - & $\mathrm{w}$ & + & - & - & - & + & + \\
\hline Sebacic acid & - & $-{ }^{b}$ & - & - & - & $+^{*}$ & $-*$ & - & - & - & - & + \\
\hline Glucuronamide & - & + & - & - & - & - & + & - & - & - & - & + \\
\hline Alaninamide & - & + & + & + & + & + & + & + & + & $\mathrm{w}$ & + & $t^{*}$ \\
\hline L-Threonine & - & + & + & + & + & + & + & + & + & + & + & $t^{*}$ \\
\hline Uridine & + & - & + & + & - & - & + & + & - & - & + & + \\
\hline Glycerol & - & $-b$ & + & $-b$ & - & - & + & + & - & + & - & - \\
\hline
\end{tabular}

${ }^{*}$ Result confirms data from the original species description.

$\dagger$ Result confirms data reported by: $a$, Kämpfer et al. (2003); b, Lebuhn et al. (2000).

$\ddagger$ Reported as variable by Kämpfer et al. (2003) or Lebuhn et al. (2000). 
ing the protocol of Scholz et al. (2006, 2008). However, primers reported to amplify more than 100 Ochrobactrum strains were unable to give any amplification with DNA from strain Ca- $34^{\mathrm{T}}$, suggesting that this strain is not closely related to O. intermedium DSM $17986^{\mathrm{T}}$ or O. anthropi DSM $6882^{\mathrm{T}}$, placed adjacent in the $16 \mathrm{~S}$ rRNA gene sequence-based dendrogram. Even primers F4 and R2, originally described to be specific for Brucella species and strains of $O$. intermedium (Romero et al., 1995; Velasco et al., 1998), did not result in positive amplification with Ca- $34^{\mathrm{T}}$.

The differences between strain Ca- $34^{\mathrm{T}}$ and O. intermedium LMG $3301^{\mathrm{T}}$ were further confirmed by amplified rDNA restriction analysis (ARDRA) of $16 \mathrm{~S}$ rRNA genes digested with restriction enzymes MboI, HpaI, BamHI, EcoRI, BsuRI, TaqI, NciI, PstI, ApaI and AluI (Supplementary Fig. S2) and RAPD fingerprinting (Fig. 2). In each experiment, strain $\mathrm{Ca}-34^{\mathrm{T}}$ gave a unique pattern. Twoprimers RAPD (TP-RAPD) patterns analysed according to the method described by Rivas et al. (2002) confirmed these differences (not shown). TP-RAPD patterns of strains from the same species are always identical (Rivas et al., 2002, 2004), while they differ between species, e.g. O. anthropi, O. lupini and O. tritici (Trujillo et al., 2005).

These results confirmed the phylogenetic distinctiveness of strain Ca- $34^{\mathrm{T}}$, which can be differentiated metabolically, chemotaxonomically and genomically from the type strains of Ochrobactrum, specially from the phylogenetically related O. intermedium (Table 2). We therefore propose a novel species Ochrobactrum ciceri sp. nov. to accommodate strain $\mathrm{Ca}-34^{\mathrm{T}}$.

\section{Description of Ochrobactrum ciceri sp. nov.}

Ochrobactrum ciceri [ci'ce.ri. L. gen. n. ciceri of chickpea (Cicer arietinum), pertaining to the habitat from which the type strain was isolated].

Cells are Gram-staining-negative (aminopeptidase-positive), aerobic (oxidase- and catalase-positive), highly motile, dumbbell-shaped short rods, commonly observed as single cells. Growth occurs on YEM agar, LB agar and $\mathrm{NA}$ at $28-37{ }^{\circ} \mathrm{C}$. Colonies $(2-3 \mathrm{~mm}$ diameter) are circular, off-white, mucoid and translucent with entire margins. No colony pigment development is observed on any medium. Of the 95 carbon sources of the Biolog GN system, 35 carbon sources show strong oxidation reactions. Biolog reactions that differentiate the type strain from its closest relative, $O$. intermedium, are as follows: glycogen, Tween 80, raffinose, L-rhamnose, trehalose, $\alpha$-ketobutyric acid, succinamic acid, glucuronamide, alaninamide, L-threonine and uridine. Positive reaction for gelatin hydrolysis can be used as a distinguishing character for rapid identification of the type strain among other Ochrobactrum type strains. Resistant to ampicillin $(10 \mu \mathrm{g})$, aztreonam $(30 \mu \mathrm{g})$, cefixime $(5 \mu \mathrm{g})$ and cephradine $(30 \mu \mathrm{g})(\beta$-lactams). The fatty acid profile is composed largely of $\mathrm{C}_{18: 1} \omega 7 c$ and $\mathrm{C}_{19: 0}$ cyclo $\omega 8 c$. In addition, significant amounts of $\mathrm{C}_{18: 0}, \mathrm{C}_{16: 0}$ and $\mathrm{C}_{18: 1} 2-\mathrm{OH}$ are present. The DNA G $+\mathrm{C}$ content of the type strain is $58.8 \mathrm{~mol} \%$. PCR with Brucella- and $O$. intermedium-specific primers $\mathrm{F} 2$ and $\mathrm{R} 4$ is negative.

The type strain, Ca- $34^{\mathrm{T}}\left(=\right.$ DSM $22292^{\mathrm{T}}=$ CCUG $\left.57879^{\mathrm{T}}\right)$, was isolated at NIBGE in 1996 from chickpea nodules.

\section{References}

Ali, Z., Cousin, S., Frühling, A., Brambilla, E., Schumann, P., Yang, Y. \& Stackebrandt, E. (2009). Description of Flavobacterium rivuli sp. nov., Flavobacterium subsaxonicum sp. nov., Flavobacterium swingsii sp. nov. and Flavobacterium reichenbachii sp. nov., isolated from a hard water rivulet. Int J Syst Evol Microbiol 59, 2610-2617.

Altschul, S. F., Madden, T. L., Schaffer, A. A., Zhang, J., Zhang, Z., Miller, W. \& Lipman, D. J. (1997). Gapped BLAST and PSI-BLAST: a new generation of protein database search programs. Nucleic Acids Res 25, 3389-3402.

Bergersen, F. J. (1961). The growth of Rhizobium in synthetic media. Aust J Biol 14, 349-360.

Cashion, P., Holder-Franklin, M. A., McCully, J. \& Franklin, M. (1977). A rapid method for the base ratio determination of bacterial DNA. Anal Biochem 81, 461-466.

Cousin, S., Brambilla, E., Yang, J. \& Stackebrandt, E. (2008). Culturable aerobic bacteria from the upstream region of a karst water rivulet. Int Microbiol 11, 91-100.

De Ley, J., Cattoir, H. \& Reynaerts, A. (1970). The quantitative measurement of DNA hybridization from renaturation rates. Eur $J$ Biochem 12, 133-142.

Doetsch, R. N. (1981). Determinative methods of light microscopy. In Manual of Methods for General Bacteriology, pp. 21-33. Edited by P. Gerhardt, R. G. E. Murray, R. N. Costilow, E. W. Nester, W. A. Wood, N. R. Krieg \& G. B. Philips. Washington, DC: American Society for Microbiology.

Hafeez, F. Y., Asad, S., Ahmad, T. \& Malik, K. A. (1995). Host specificity and characterization of fast growing rhizobia from Macroptilium atropurpureum cv. Siratro in Pakistan. Soil Biol Biochem 27, 729-733.

Holmes, B., Popoff, M., Kiredjian, M. \& Kersters, K. (1988). Ochrobactrum anthropi gen. nov., sp. nov. from human clinical specimens and previously known as Group Vd. Int J Syst Bacteriol 38, 406-416.

Huber, B., Scholz, H. C., Kämpfer, P., Falsen, E., Langer, S. \& Busse, H.-J. (2010). Ochrobactrum pituitosum sp. nov., isolated from an industrial environment. Int J Syst Evol Microbiol 60, 321-326.

Huß, V. A. R., Festl, H. \& Schleifer, K. H. (1983). Studies on the spectrophotometric determination of DNA hybridization from renaturation rates. Syst Appl Microbiol 4, 184-192.

Kämpfer, P. \& Kroppenstedt, R. M. (1996). Numerical analysis of fatty acid patterns of coryneform bacteria and related taxa. Can J Microbiol 42, 989-1005.

Kämpfer, P., Buczolits, S., Albrecht, A., Busse, H.-J. \& Stackebrandt, E. (2003). Towards a standardized format for the description of a novel species (of an established genus): Ochrobactrum gallinifaecis sp. nov. Int J Syst Evol Microbiol 53, 893-896.

Kämpfer, P., Scholz, H. C., Huber, B., Falsen, E. \& Busse, H.-J. (2007). Ochrobactrum haematophilum sp. nov. and Ochrobactrum pseudogrignonense sp. nov., isolated from human clinical specimens. Int J Syst Evol Microbiol 57, 2513-2518.

Kämpfer, P., Sessitsch, A., Schloter, M., Huber, B., Busse, H. J. \& Scholz, H. C. (2008). Ochrobactrum rhizosphaerae sp. nov. and 
Ochrobactrum thiophenivorans sp. nov., isolated from the environment. Int J Syst Evol Microbiol 58, 1426-1431.

Kimura, M. (1980). A simple method for estimating evolutionary rates of base substitutions through comparative studies of nucleotide sequences. J Mol Evol 16, 111-120.

Labrenz, M., Collins, M. D., Lawson, P. A., Tindall, B. J., Braker, G. \& Hirsch, P. (1998). Antarctobacter heliothermus gen. nov., sp. nov., a budding bacterium from hypersaline and heliothermal Ekho Lake. Int J Syst Bacteriol 48, 1363-1372.

Lebuhn, M., Achouak, W., Schloter, M., Berge, O., Meier, H., Barakat, M., Hartmann, A. \& Heulin, T. (2000). Taxonomic characterization of Ochrobactrum sp. isolates from soil samples and wheat roots, and description of Ochrobactrum tritici sp. nov. and Ochrobactrum grignonense sp. nov. Int J Syst Evol Microbiol 50, 2207-2223.

Mesbah, M., Premachandran, U. \& Whitman, W. B. (1989). Precise measurement of the $\mathrm{G}+\mathrm{C}$ content of deoxyribonucleic acid by highperformance liquid chromatography. Int J Syst Bacteriol 39, 159-167.

Ngom, A., Nakagawa, Y., Sawada, H., Tsukahara, J., Wakabayashi, S., Uchiumi, T., Nuntagij, A., Kotepong, S., Suzuki, A. \& other authors (2004). A novel symbiotic nitrogen-fixing member of the Ochrobactrum clade isolated from root nodules of Acacia mangium. J Gen Appl Microbiol 50, 17-27.

Rivas, R., Velázquez, E., Palomo, J. L., Mateos, P., García-Benavides, P. \& Martínez-Molina, E. (2002). Rapid identification of Clavibacter michiganensis subspecies sepedonicus using two primers random amplified polymorphic DNA (TP-RAPD) fingerprints. Eur J Plant Pathol 108, 179-184.

Rivas, R., Willems, A., Palomo, J. L., García-Benavides, P., Mateos, F. P., Martínez-Molina, E., Gillis, M. \& Velázquez, E. (2004). Bradyrhizobium betae sp. nov., isolated from roots of Beta vulgaris affected by tumourlike deformations. Int J Syst Evol Microbiol 54, 1271-1275.

Romero, C., Gamazo, C., Pardo, M. \& Lopez-Goni, I. (1995). Specific detection of Brucella DNA by PCR. J Clin Microbiol 33, 615-618.

Saitou, N. \& Nei, M. (1987). The neighbor-joining method: a new method for reconstructing phylogenetic trees. Mol Biol Evol 4, 406425.

Sasser, M. (1990). Identification of bacteria by gas chromatography of cellular fatty acids. MIDI Technical Note 101. Newark, DE: MIDI Inc.

Scholz, H. C., Tomaso, H., Dahouk, S. A., Witte, A., Schloter, M. \& Kämpfer, P. (2006). Genotyping of Ochrobactrum anthropi by recAbased comparative sequence, PCR-RFLP, and 16S rRNA gene analysis. FEMS Microbiol Lett 257, 7-16.

Scholz, H. C., Al Dahouk, S., Tomaso, H., Neubauer, H., Witte, A., Schloter, M., Kämpfer, P., Falsen, E., Pfeffer, M. \& Engel, M. (2008). Genetic diversity and phylogenetic relationships of bacteria belonging to the Ochrobactrum-Brucella group by recA and 16S rRNA genebased comparative sequence analysis. Syst Appl Microbiol 31, 1-16.
Stackebrandt, E. \& Ebers, J. (2006). Taxonomic parameters revisited: tarnished gold standards. Microbiol Today 33, 152-155.

Tan, Z.-Y., Xu, X.-D., Wang, E.-T., Gao, J.-L., Martínez-Romero, E. \& Chen, W.-X. (1997). Phylogenetic and genetic relationships of Mesorhizobium tianshanense and related rhizobia. Int J Syst Bacteriol 47, 874-879.

Teyssier, C., Marchandin, H., Siméon de Buochberg, M., Ramuz, R. \& Jumas-Bilak, E. (2003). Atypical 16S rRNA gene copies in Ochrobactrum intermedium strains reveal a large genomic rearrangement by recombination between rrn copies. J Bacteriol 185, 29012909.

Teyssier, C., Marchandin, H., Jean-Pierre, H., Darbas, H., Siméon de Buochberg, M., Diego, I., Gouby, A. \& Jumas-Bilak, E. (2005). Molecular and phenotypic features for identification of the opportunistic pathogens Ochrobactrum spp. J Med Microbiol 54, 945953.

Teyssier, C., Marchandin, H., Jean-Pierre, H., Masnou, A., Dusart, G. \& Bilak, E. J. (2007). Ochrobactrum pseudintermedium sp. nov., a novel member of the family Brucellaceae, isolated from human clinical samples. Int J Syst Evol Microbiol 57, 1007-1013.

Tien, T. M., Gaskins, M. H. \& Hubbel, D. H. (1979). Plant growth substances produced by Azospirillum brasilense and their effect on the growth of pearl millet (Pennisetum americanum L.). Appl Environ Microbiol 37, 1016-1024.

Tripathi, A. K., Verma, S. C., Chowdhury, S. P., Lebuhn, M., Gattinger, A. \& Schloter, M. (2006). Ochrobactrum oryzae sp. nov., an endophytic bacterial species isolated from deep-water rice in India. Int J Syst Evol Microbiol 56, 1677-1680.

Trujillo, M. E., Willems, A., Abril, A., Planchuelo, A. M., Rivas, R., Ludena, D., Mateos, P. F., Martinez-Molina, E. \& Velazquez, E. (2005). Nodulation of Lupinus albus by strains of Ochrobactrum lupini sp. nov. Appl Environ Microbiol 71, 1318-1327.

Valverde, A. M., Benito, M. \& Lorenzo, M. (2005). The brown adipose cell: a model for understanding the molecular mechanisms of insulin resistance. Acta Physiol Scand 183, 59-73.

Velasco, J., Romero, C., López-Goñi, I., Leiva, J., Díaz, R. \& Moriyón, I. (1998). Evaluation of the relatedness of Brucella spp. and Ochrobactrum anthropi and description of Ochrobactrum intermedium sp. nov., a new species with a closer relationship to Brucella spp. Int $J$ Syst Bacteriol 48, 759-768.

Vincent, J. M. (1970). A Manual for the Practical Study of the Root Nodule Bacteria. IBP Handbook no. 15. Oxford: Blackwell Scientific.

Zurdo-Piñeiro, J. L., Rivas, R., Trujillo, M. E., Vizcaíno, N., Carrasco, J. A., Chamber, M., Palomares, M., Mateos, P. F., Martínez-Molina, E. \& Velázquez, E. (2007). Ochrobactrum cytisi sp. nov., isolated from nodules of Cytisus scoparius in Spain. Int J Syst Evol Microbiol 57, 784788. 